\title{
Study on knowledge and practice regarding no scalpel vasectomy (NSV) among male members of eligible couples in a rural community of West Bengal, India
}

\author{
Anand Kishore ${ }^{1}$, Tania Pan ${ }^{2 *}$, Narendra Nath Naskar ${ }^{1}$
}

\begin{abstract}
${ }^{1}$ Department of Public Health Administration, ${ }^{2}$ Department of Preventive and Social Medicine, All India Institute of Hygiene and Public Health, Kolkata, West Bengal, India
\end{abstract}

Received: 04 June 2018

Accepted: 28 June 2018

\author{
*Correspondence: \\ Dr. Tania Pan, \\ E-mail: taniapan1902@gmail.com
}

Copyright: ( $)$ the author(s), publisher and licensee Medip Academy. This is an open-access article distributed under the terms of the Creative Commons Attribution Non-Commercial License, which permits unrestricted non-commercial use, distribution, and reproduction in any medium, provided the original work is properly cited.

\section{ABSTRACT}

Background: No Scalpel Vasectomy (NSV) was introduced in India with the aim to increase male participation in family planning methods. But in spite of the best of efforts, it has failed to achieve its goal. The current acceptance of NSV in India has declined from 1 percent (NFHS 3) to 0.3 percent (NFHS 4). This study was done to get an insight regarding knowledge and practice of NSV and elicit the perceived reasons for underutilization of vasectomy in the community.

Methods: A community-based cross-sectional study was conducted among 340 male members of eligible couples in six randomly selected villages in Singur from September 2017 to February 2018. Each respondent was interviewed using a structured schedule. All ethical issues were addressed. Data entry and analysis was done using SPSS version 16.0 .

Results: Out of 340 participants, $57.9 \%$ have heard of NSV. Around $61 \%$ of the participants have heard of the male contraceptives from media. Although $57.8 \%$ knew it to be method of permanent male contraception, only $15.7 \%$ were aware that NSV does not need hospitalization. The most frequently reported reasons for underutilization of NSV in the community was fear of surgery $(51.3 \%)$ and loss of earning due to prolonged bed rest $(44.2 \%)$. Overall, the proportion of male members of the eligible couples who underwent NSV was $0.6 \%$.

Conclusions: Promotional activities should focus on bridging the prevailing information gap regarding NSV among the potential clients. The IEC activities including interpersonal communication and group counselling sessions must deal with their apprehensions thereby changing the behaviour of the society.

Keywords: Contraceptives, Eligible couples, Rural community, Sterilization, Vasectomy

\section{INTRODUCTION}

Is population explosion a boon or a curse? For the developed European nations, like Spain and Italy, where the population is decreasing, this might be considered as a boon. However, for the developing countries like India, population explosion is a curse and is damaging to the development of the country and its society. The developing countries already facing a lack in their resources, and with the rapidly increasing population, the resources available per person are reduced further, leading to increased poverty, malnutrition, and other large population-related problems. ${ }^{1}$

Although, the crown of the world's most populous country is on China's head for decades, India is all set to take the numero uno position by 2030. With the population growth rate at $1.58 \%$, India is predicted to have more than 1.53 billion people by the end of $2030 .^{2}$ However, it is interesting to know that India was the first 
country to introduce a national family planning program in the year 1952 with the main objective to reduce the growth rate so as to stabilize the population at a level consistent with the needs and potential of national economy. ${ }^{3}$

Female sterilization is the most popular method of birth control in India. But birth control for men in India has barely progressed since its introduction in the year 1992, even though vasectomy is a minor procedure with minimal side effects. ${ }^{4}$ Cost-wise also, the ratio is about 5 vasectomies to one tubal ligation. ${ }^{5}$ Failure rate of vasectomy is only 0.15 percent. $^{6}$ Although female sterilization is prone to infections and worse, so many women opt for it because they are weary of childbirth over half of Indian women between 15 and 49 years are anemic because of a poor diet and frequent pregnancies. ${ }^{7}$

NSV technique was introduced in India with the aim to increase male participation in family planning methods. ${ }^{8}$ Increased use of temporary contraceptives has been reported in India, but the use of permanent contraception is very low. So, to overcome all these barriers the Government of India have taken some notable steps to increase the rates of male sterilization. An incentive of Rs.1100/- are made available to clients/acceptors after the procedure. In the case of failure, the government gives an amount of Rs.30000/- to the client as compensation. A five days leave is allotted for those employed in the Government sector. Despite of the best of efforts and even though NSV being a simple and safe method, it has failed to achieve its goal. ${ }^{9}$

This is evident by the fact that the current acceptance of NSV in India has declined from 1 percent (NFHS 3) to 0.3 percent (NFHS 4) and in West Bengal where most of the health indicators are doing fairly good, coverage of vasectomy is only 0.1 per cent (NFHS 4) which is not only well below the national average but also less than the last NFHS where it was 0.8 percent (NFHS 3). ${ }^{10,11}$ Also, there is a magnanimous difference between female and male sterilization in India - 36 percent female as against 0.3 percent male sterilization (NFHS 4). ${ }^{10}$ Thus, it is quite evident that no scalpel vasectomy is highly underutilized as a method of male contraception.

Keeping this background in mind, this study was done among the male members of eligible couples with an aim to get an insight regarding knowledge and practice of NSV and elicit the perceived reasons for underutilization of vasectomy in the community.

\section{METHODS}

This study was a cross-sectional community-based observational study conducted from September 2017 to February 2018 among male members of the eligible couples residing in six randomly selected villages of Singur block, West Bengal. Since no previous data regarding this topic of interest in this setting was available, so a pilot study was conducted in a similar rural setting among 40 male individuals belonging to eligible couple (wherein the wives were in the reproductive age group) and the proportion of male members who have heard of NSV as "a method of male contraception" was found to be $30 \%$.

Considering the anticipated population proportion to be $30 \%, 95 \%$ confidence level and 5\% absolute error and $5 \%$ non-response rate, the final sample size was 340 . Simple random sampling was adopted. Line listing of all the male members of the eligible couples was done from the eligible couple register in the selected villages and number of participants from each village was calculated by Population Proportional to Size sampling.

Data collection was done with help of predesigned pretested schedule. Data entry and analysis were performed using statistical software SPSS (IBM SPSS Statistics for Windows, Version 16.0). Descriptive statistics (mean \pm standard deviation [SD] and median for the continuous variables and frequency in percentage for the categorical variables) were used to describe the demographic, knowledge and perceived reasons for underutilization of NSV. Ethical approval was obtained from the Institutional Ethics Committee.

\section{RESULTS}

Out of 340 study participants, $106(31.2 \%)$ belonged to the age group 29-38 years. The mean (SD) age was 37.5 (8.3) years. Among the study participants, 288 (84.7\%) were Hindu.

The mean (SD) years of schooling was 7.5 (3.3) years. 31 $(9.1 \%)$ of the participants were illiterate. The proportion of the participants who were educated up to primary was $46.5 \%$. The proportion of participants who were unemployed were $3.5 \%$. The mean (SD) per capita monthly income was Rs. 2144.10 (Rs.1247.80), with 112 $(32.9 \%)$ belong the SES Class III (according to Modified B. G. Prasad Scale 2017).

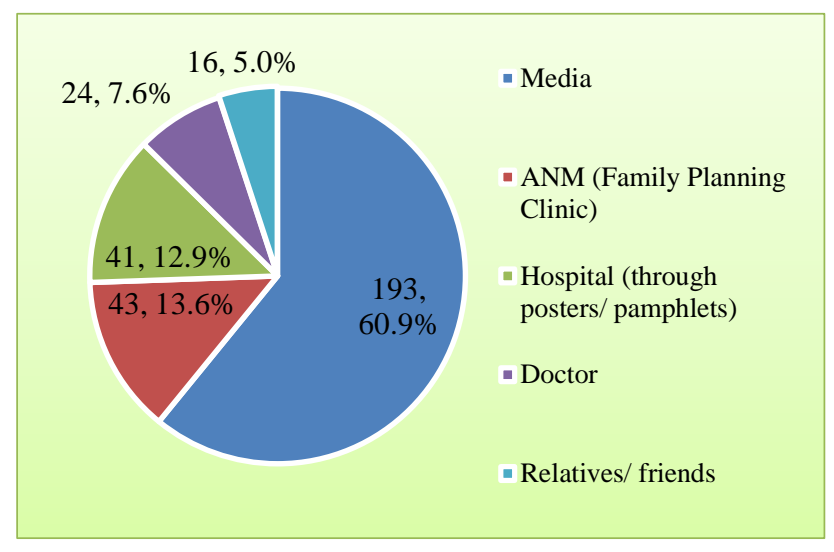

Figure 1: Distribution of study participants according to their source of knowledge of male contraceptives $(\mathbf{n}=317)$. 
Table 1: Distribution of study participants according to knowledge of male contraceptives $(n=340)$.

\begin{tabular}{|l|}
\hline \multicolumn{2}{|l|}{ Questions } & No. $(\%)$ \\
\hline \multicolumn{2}{|l|}{ Have you heard of male contraceptives? } \\
\hline Yes
\end{tabular}

Table 2: Distribution of study participants according to knowledge of NSV $(n=197)$.

\begin{tabular}{|c|c|}
\hline Questions & No. $(\%)$ \\
\hline \multicolumn{2}{|c|}{ NSV as a method of male contraception } \\
\hline Permanent & $114(57.8)$ \\
\hline Temporary & $83(42.2)$ \\
\hline \multicolumn{2}{|c|}{ Hospitalization needed to perform NSV } \\
\hline Yes & $108(54.8)$ \\
\hline No & $31(15.7)$ \\
\hline Don't know & $58(29.5)$ \\
\hline \multicolumn{2}{|l|}{ Side effects of NSV * } \\
\hline Local pain & $142(72.1)$ \\
\hline Swelling & $107(54.3)$ \\
\hline Infection & $53(26.9)$ \\
\hline Recanalization & $14(7.1)$ \\
\hline \multicolumn{2}{|c|}{$\begin{array}{l}\text { Incentives given by the government if someone } \\
\text { undergoes NSV }\end{array}$} \\
\hline Yes & $106(53.8)$ \\
\hline No & $37(18.8)$ \\
\hline Don’t know & $31(27.4)$ \\
\hline \multicolumn{2}{|l|}{ Amount of incentive given $(n=106)$} \\
\hline Correct & $31(29.2)$ \\
\hline Incorrect & $75(70.8)$ \\
\hline \multicolumn{2}{|c|}{$\begin{array}{l}\text { Insurance given by government in case of } \\
\text { vasectomy failure }\end{array}$} \\
\hline Yes & $52(26.4)$ \\
\hline No & $23(11.7)$ \\
\hline Don’t know & $122(61.9)$ \\
\hline \multicolumn{2}{|c|}{$\begin{array}{l}\text { Source of information regarding insurance } \\
\text { provided }(n=52)\end{array}$} \\
\hline Media & $10(19.2)$ \\
\hline ANM (family planning clinic) & $12(23.1)$ \\
\hline Hospital (though posters/ pamphlets) & $27(51.9)$ \\
\hline Doctor & $3(5.8)$ \\
\hline \multicolumn{2}{|l|}{ NSV better than female sterilization } \\
\hline Yes & $51(25.9)$ \\
\hline No & $113(57.4)$ \\
\hline Don't know & $33(16.7)$ \\
\hline
\end{tabular}

Also, $28(8.2 \%)$ were married below the age of 21 years. Among their partners, 22 (6.5\%) were married below the age of 18 years. The mean (SD) duration of marriage was 15.3 (6.5). Of the participants, $59(17.4 \%)$ did not have any children yet, while $127(37.4 \%)$ had two children and $61(17.9 \%)$ had three or more children.

Out of 340 participants, $317(93.2 \%)$ have heard of male contraceptives (Table 1). Overall, $57.9 \%$ of the study participants have heard of NSV. Around $61 \%$ of the participants have heard of the male contraceptives from media (television, radio, newspaper), while $13.6 \%$ have heard from ANM in Family Planning Clinics (Figure 1).

Table 3: Distribution of study participants according to their perceived reasons for underutilization of NSV in the community $(n=197)$.

\begin{tabular}{|ll|}
\hline $\begin{array}{ll}\text { Reasons for underutilization of NSV in } \\
\text { the community * }\end{array}$ & No. $(\%)$ \\
\hline $\begin{array}{ll}\text { 1.Fear of undergoing surgical procedure } \\
\text { 2. Fear of weakness }\end{array}$ & $101(51.3)$ \\
\hline $\begin{array}{l}\text { 3. Loss of earning due to prolonged bed rest } \\
\text { 4. Decrease in sexual desire }\end{array}$ & $24(44.2)$ \\
\hline $\begin{array}{l}\text { 5. Availability of alternative family } \\
\text { planning methods }\end{array}$ & $75(38.1)$ \\
$\begin{array}{l}\text { 6. Belief that family planning is the } \\
\text { responsibility of women }\end{array}$ & $56(28.4)$ \\
\hline $\begin{array}{l}\text { 7. Unable to have children if any child dies } \\
\text { 8. Unable to remarry/ give birth to } \\
\text { children with second wife after death/ } \\
\text { divorce from first wife }\end{array}$ & $54(27.4)$ \\
\hline * Multiple response & $16(8.1)$ \\
\hline
\end{tabular}

Table 2 shows the distribution of study participants according to knowledge of NSV $(n=197)$. Table 3 shows the perceived reasons for underutilization of NSV in the community $(\mathrm{n}=197)$.

Out of 188 study participants who had two or more children and were eligible for permanent sterilization, $117(62.2 \%)$ participants or their partners had undergone permanent sterilization. Among them, only $2(1.7 \%)$ had undergone NSV. Overall, the proportion of male members of the eligible couples who underwent NSV was $0.6 \%$.

\section{DISCUSSION}

Among the study participants, $93.2 \%$ have heard of male contraceptives. Overall, $57.9 \%$ of the study participants have heard of NSV as a method of male contraception. This figure is lower than $70 \%$ as reported by a study in Punjab conducted in 2012 among 225 married and unmarried males. ${ }^{12}$ This is also lower than figures reported by studies in urban slums of Maharashtra. ${ }^{13,14}$

In the present study, around $61 \%$ of the participants have heard of the male contraceptives from media (television, radio, newspaper) and $12.9 \%$ through posters and pamphlets in hospitals. This finding is in line with the role of mass media in spreading awareness and is also comparable with those reported by other studies. ${ }^{13,15}$ However, only $13.6 \%$ have heard from ANM in family 
planning clinics and $7.6 \%$ from doctors. This is similar to $24.7 \%$ reported in another study. ${ }^{13}$ Relatives and friends were not an active source of information in our study participants. Thus, we can conclude that mouth to mouth publicity of sterilization methods is not very effecting in our study setting. Among 197 participants who have heard of NSV, $57.8 \%$ knew of NSV to be method of permanent male contraception.

This is lower than $82 \%$ reported by a study ${ }^{[16]}$ in rural Bangalore in 2014. This is also less than $70.2 \%$ as reported by another study in urban setting in Navi Mumbai in 2016-17. ${ }^{13}$ Only $15.7 \%$ knew that hospitalization is not necessary to undergo NSV. Also $53.8 \%$ were aware that incentive is given by the Government if someone undergoes NSV. However, only $29.2 \%$ of them correctly knew of the amount of incentive given by the Government.

Only $26.4 \%$ knew of insurance coverage by the Government in case of vasectomy failure. Another study in the same setting reported that $12 \%$ were aware of provision of insurance. ${ }^{16}$ This difference may be attributed to the fact that the referred study was conducted in 2015 and with passage of time improved communication means have led to increased awareness which eventually resulted in better performance of the knowledge parameters as reflected by the current study. Only $25.9 \%$ agreed that NSV was better than female sterilization. This is nearly similar to $31 \%$ reported by another study in Punjab. ${ }^{12}$

The most frequent cause of apprehension in adopting NSV was fear of surgical procedure $(51.3 \%)$, followed by loss of earning due to prolonged bed rest $(44.2 \%)$. It is most likely that the advantages of NSV - no incision, no stitches, no hospitalization, minimal pain - is not effectively propagated. In the rural setting, where most of the men are farmers or labourers, the notion that hospitalization and prolonged bed rest would lead to loss of earning seems to have a bearing on the utilization of NSV.

It is reflected from our findings that underutilization of NSV in the community is mainly due to misconceptions that prevail and beliefs that have passed down traditionally. In our study, $28.4 \%$ believe that family planning is the responsibility of women. This is quite lower than $69.4 \%$ reported by a study in urban slums of Mumbai. ${ }^{13}$ This finding is agreeable with the fact that males, who have always taken the upper hand in gender relations, end up thrusting the responsibility of family planning on women solely.

The notion that vasectomy leads to decrease in sexual desire $(12.2 \%)$ and weakness $(26.4 \%)$ has further worsened the situation. This aspect was also highlighted in another survey where it was noted that "men would not tell other people if they had been sterilized, fearing being shamed and taunted by community members, who might refer to them using such words as namard (meaning impotent)". ${ }^{17}$ In a survey in Tanzania, the respondents reported that vasectomy was equivalent to castration. ${ }^{18}$

The availability of other family planning methods as reported by $38.1 \%$, have pointed out that males would prefer women to undergo tubectomy, or use other temporary methods rather than themselves undergoing vasectomy. Furthermore, $27.4 \%$ have stated that inability to have children if any child dies after undergoing permanent sterilization as a cause of apprehension. Also, $8.1 \%$ have said that it would not be possible to remarry after undergoing vasectomy. This is similar to that reported by other studies. ${ }^{19,20}$

In the present study, of the 117 eligible couples who have adopted permanent method of contraception, only two had undergone NSV, despite $25.9 \%$ agreed that vasectomy is a safer method than tubectomy. The overall utilization of NSV is $0.6 \%$ among the eligible couples. Although, this figure is slightly more than the reported figures for West Bengal (0.1\%) and India (0.3\%), still it is far less. It is obvious that there is a large gap between the knowledge and practice of vasectomy. This calls for a focussed approach to address the major barriers to male sterilization.

\section{CONCLUSION}

The present study found the most frequent causes of underutilization of NSV to be fear of surgery and loss of earning due to prolonged bed rest. The need of the hour is promoting NSV as an effective simple, painless, day care procedure with very few complications. Also, the provision of cash incentives and insurance in cases of vasectomy failure needs to be highlighted. It is suggested to avoid the using the word "operation" in relation to NSV in the IEC materials. Also, better incentives should be provided to men adopting this procedure.

Efforts need to be put on to address the prevailing misconceptions and beliefs related to vasectomy. Interpersonal communication and group counselling sessions involving potential clients should be designed specifically for information exchange and discussion to alleviate their fear.

Promotional activities though mass media should be accelerated. Involvement of community leaders, religious leaders and distinguished persons of the society for this cause should be considered. Also, airing the stories of satisfied clients through the media would likely boost the acceptability of NSV as a popular family planning method in the community.

\section{Funding: No funding sources \\ Conflict of interest: None declared}

Ethical approval: The study was approved by the Institutional Ethics Committee 


\section{REFERENCES}

1. University of Bridgeport. Population Explosion in India. Available at http://www1bpt.bridgeport.edu/ darmri/population_e xplosion.html. Accessed on 17 September 2017.

2. Mamanshetty SV. Growth of population impact on environmental degradation: an over view of India. Elixir Agriculture. 2012;51:10877-80.

3. Santhya KG. Changing family planning scenario in India: an overview of recent evidence. Population Council, New Delhi; 2003;17:1-44.

4. Kumar V, Kaza RM, Singh I, Singhal S, Kumaran V. An evaluation of the no-scalpel vasectomy technique. BJU Int. 1999;83(3):283-4.

5. Rastogi A. Claiming Dignity: Reproductive Rights \& the Law. Human Rights Law Network (HRLN); 2009. Available at https://hrln.org/claiming-dignityreproductive-rights-the-law-2/ Accessed 11 January 2018.

6. Association of Reproductive Health Professionals Choosing a birth control method. Failure rate tables. ARHP. 2011:79. Available at http://www.arhp.org/uploadDocs/choosingqrg.pdf Accessed 18 September 2017.

7. Development Initiatives. Global Nutrition Report 2017: Nourishing the SDGs. Bristol, UK 2017. Available at http://globalnutritionreport.org/thereport/ Accessed 17 February 2018.

8. Rajoura OP, Meena GS, Kaza RCM, Bhasin SK. Acceptability of no-scalpel vasectomy at a male family welfare centre in Delhi. J Fam Welfare. 2003;49(2):10-3.

9. "Vasectomy Fortnight - Information for General Public: On NSV Services. Department of Health and Family Welfare, Government of Delhi; 2017. Available http://delhi.gov.in/wps/wcm/connect/doit_health/Hea lth/Home/Family+Welfare/Family+Planning.html Accessed 23 September 2017.

10. International Institute for Population Sciences (IIPS), ICF. National Family Health Survey (NFHS-4), 2015-16: India. Mumbai, 2017.

11. International Institute for Population Sciences (IIPS), ICF. National Family Health Survey (NFHS-4), India, 2015-16: West Bengal. Mumbai, 2017.
12. Sood A, Pahwa P. Vasectomy: a study of attitudes, beliefs, knowledge and practices among literate men in Punjab, India. Int $\mathbf{J}$ Reprod Contracept Obstet Gynecol. 2014;3:418-23.

13. Nair GR, Wadke R, Relwani N, Mahadik V, Anjenaya S. Knowledge and attitude of married men towards vasectomy in an urban slum of Navi Mumbai. Int $\mathrm{J}$ Community Med Public Health 2017;4:4563-8.

14. Khan MM, Shahauddin ST, Shroff AG. Study of Knowledge and Practice of Contraception in Urban Slum Community, Mumbai. Int J Current Med Applied Sci. 2014;3:35-41.

15. Dasgupta A, Das MK, Das S. Perception towards no scalpel vasectomy (NSV): a community-based study among married males in a rural area of West Bengal. Int J Health Sci Res. 2015;5:30-6.

16. Madhukumar S, Pavithra MB. A study about perceptions, attitude, and knowledge among men toward vasectomy in Bangalore rural population. Int J Med Sci Public Health. 2015;4:1066-70.

17. Scott B, Alam D, Raman S. Factors affecting acceptance of vasectomy in Uttar Pradesh: Insights from community-based, participatory qualitative research. The RESPOND Project Study Series: Contributions to Global Knowledge - Report No. 3. New York, 2011.

18. Frajzyngier V, Bunce A, Lusiola G, Riwa P, Kanama J, Achwal I, et al. Factors affecting vasectomy acceptability in the Kigoma region of Tanzania. The ACQUIRE Project E\&R Study No. 5. New York, 2006.

19. Bunce A, Guest G, Searing H, Frajzyngier V, Riwa $\mathrm{P}$, Kanama J, et al. Factors affecting vasectomy acceptability in Tanzania. Int Fam Plan Perspect. 2007;33:13-21.

20. Dibaba A. Rural men and their attitude towards vasectomy as means of contraception in Ethiopia. Tropical Doctor. 2001;31:100-2.

Cite this article as: Kishore A, Pan T, Naskar NN. Study on knowledge and practice regarding no scalpel vasectomy (NSV) among male members of eligible couples in a rural community of West Bengal, India. Int J Reprod Contracept Obstet Gynecol 2018;7:3294-8. 